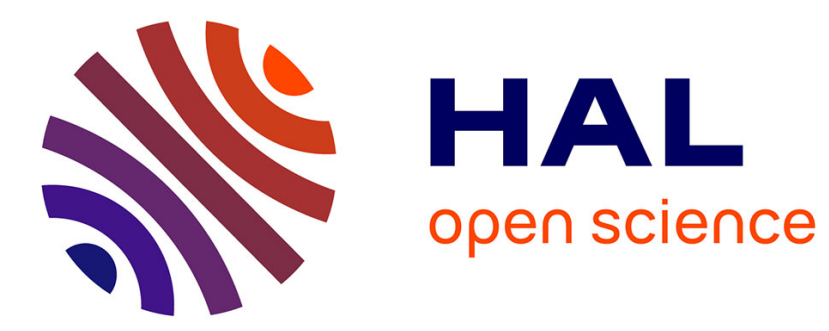

\title{
Spatial targeting of agri-environmental policy and urban development
}

\author{
Thomas Coisnon, Walid Oueslati, Julien Salanié
}

\section{To cite this version:}

Thomas Coisnon, Walid Oueslati, Julien Salanié. Spatial targeting of agri-environmental policy and urban development. 2013. halshs-00795815

\section{HAL Id: halshs-00795815 https://shs.hal.science/halshs-00795815}

Preprint submitted on 28 Feb 2013

HAL is a multi-disciplinary open access archive for the deposit and dissemination of scientific research documents, whether they are published or not. The documents may come from teaching and research institutions in France or abroad, or from public or private research centers.
L'archive ouverte pluridisciplinaire HAL, est destinée au dépôt et à la diffusion de documents scientifiques de niveau recherche, publiés ou non, émanant des établissements d'enseignement et de recherche français ou étrangers, des laboratoires publics ou privés. 
13, allée François Mitterrand

BP 13633

49100 ANGERS Cedex 01

Tél. : +33 (0) 241962106

Web : http://www.univ-angers.fr/granem

\section{Spatial targeting of agri-environmental policy and urban development}

\section{Thomas Coisnon}

GRANEM, Université d'Angers

\section{Walid Oueslati}

GRANEM, Université d'Angers

Centre for Rural Economy, University of Newcastle

\section{Julien Salanié}

GRANEM, Université d'Angers

février 2013

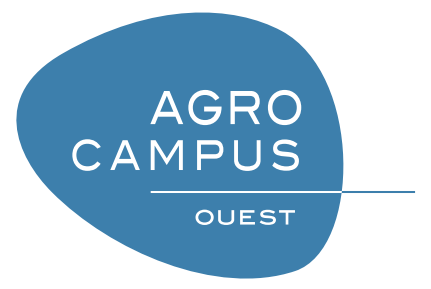

Document de travail du GRANEM n ${ }^{\circ}$ 2013-01-038 


\section{Spatial targeting of agri-environmental policy and urban development}

Thomas Coisnon, Walid Oueslati et Julien Salanié

Document de travail du GRANEM n 2013-01-037

février 2013

Classification JEL : R14, R21, Q18, Q24, Q25

Mots-clés: artificialisation des terres, étalement urbain, mitage, rente foncière, modèle monocentrique, agriculture, politiques agri-environnementales, ciblage spatial, pollution agricole.

Keywords: land development, urban sprawl, leapfrog, land rent, monocentric model, farming, agrienvironmental policy, spatial targeting, agricultural pollution.

Résumé : Il existe de manière assez répandue un soutien public destiné à la préservation d'aménités naturelles, telles que des lacs, des rivières ou des zones humides, qui s'accompagne d'efforts pour les protéger de la pollution agricole. Les politiques agri-environnementales contribuent à ces efforts en incitant les agriculteurs à adopter des pratiques respectueuses de l'environnement au sein de ces écosystèmes. Une politique agri-environnementale territorialisée favorise la préservation d'aménités naturelles, et peut ainsi influencer le choix de localisation résidentielle des ménages. L'objectif de ce papier est d'étudier l'étendue de ces effets sur une structure urbaine spatialisée. Nous utilisons un modèle de ville monocentrique dans lequel nous incluons le comportement des agriculteurs vis-à-vis d'une politique agri-environnementale. Nous constatons que l'introduction d'une politique agri-environnementale territorialisée peut mener à l'apparition de développement urbain supplémentaire, qui peut se révéler contradictoire par rapport à l'objectif même de la politique.

\footnotetext{
Abstract: Widespread public support exists for the provision of natural amenities, such as lakes, rivers or wetlands, and for efforts to preserve these from agricultural pollution. Agri-environmental policies contribute to these efforts by encouraging farmers to adopt environmentally friendly practices within the vicinity of these ecosystems. A spatially targeted agri-environmental policy promotes natural amenities and may thereby affect household location decisions. The purpose of this paper is to investigate the extent of these impacts on the spatial urban structure. We extend a monocentric city model to include farmers' responses to an agri-environmental policy. Our main findings are that the implementation of a spatially targeted agri-environmental policy may lead to some additional urban development, which could conflict with the aim of the policy.
}

\section{Thomas Coisnon}

Agrocampus Ouest

Université d'Angers

thomas.coisnon@agrocampus-ouest.fr>

Walid Oueslati

Agrocampus Ouest

Université d'Angers

Centre for Rural Economy

University of Newcastle

walid.oueslati@agrocampus-ouest.fr

walid.oueslati@ncl.ac.uk

Julien Salanié

Agrocampus Ouest

Université d'Angers

julien.salanie@agrocampus-ouest.fr

(c) 2013 by Thomas Coisnon, Walid Oueslati and Julien Salani. All rights reserved. Short sections of text, not to exceed two paragraphs, may be quoted without explicit permission provided that full credit, including @ notice, is given to the source.

(c) 2013 par Thomas Coisnon, Walid Oueslati et Julien Salani. Tous droits réservés. De courtes parties du texte, n'excédant pas deux paragraphes, peuvent être citées sans la permission des auteurs, à condition que la source soit citée. 


\title{
Spatial targeting of agri-environmental policy and urban development
}

\author{
Thomas Coisnon $^{a *}$, Walid Oueslati ${ }^{a, b}$ and Julien Salanié ${ }^{a}$ \\ ${ }^{a}$ GRANEM, Agrocampus Ouest, 2 rue le Notre, 49000 Angers, France. \\ ${ }^{b}$ Centre for Rural Economy, University of Newcastle, Newcastle, NE1 7RU, UK.
}

February 6, 2013

\begin{abstract}
Widespread public support exists for the provision of natural amenities, such as lakes, rivers or wetlands, and for efforts to preserve these from agricultural pollution. Agri-environmental policies contribute to these efforts by encouraging farmers to adopt environmentally friendly practices within the vicinity of these ecosystems. A spatially targeted agri-environmental policy promotes natural amenities and may thereby affect household location decisions. The purpose of this paper is to investigate the extent of these impacts on the spatial urban structure. We extend a monocentric city model to include farmers' responses to an agri-environmental policy. Our main findings are that the implementation of a spatially targeted agrienvironmental policy may lead to some additional urban development, which could conflict with the aim of the policy.
\end{abstract}

JEL classification : R14, R21, Q18, Q24, Q25.

Keywords : Land development, Urban sprawl, Leapfrog, Land rent, Monocentric model, Farming, Agri-environmental policy, Spatial targeting, Agricultural pollution.

\section{Introduction}

Agri-environmental policies focus on protecting and preserving natural resources and ecosystem services, although they differ throughout the world in terms of design and level of importance. Despite their international variability, agri-environmental policies (AEPs) share some common features: farmers are enrolled in environmental programs on a voluntary basis in exchange for payment (Wunder et al. 2008; Baylis et al., 2008). AEPs implementation has raised several efficiency concerns. First, informational asymmetries between the contractors (i.e. farmers as 'agents' and the State as 'principal') can induce inefficiencies. These arise either due to the fact that farmers' implementation costs are unknown to the principal (adverse selection: e.g. Latacz-Lohmann \& Van der Hamsvoort, 1997; Canton et al., 2009), or because the principal cannot control farmers'

${ }^{*}$ Corresponding author. Email: thomas.coisnon@agrocampus-ouest.fr 
actions after contract implementation (moral hazard: e.g. Choe \& Fraser, 1999; Ozanne et al. 2001). Secondly, as a result of budget constraints, not all of the land can be included within an AEP. This calls for targeting strategies. Babcock et al. (1997) have shown the superiority of benefit-cost targeting strategies over environmental benefits or land costs targeting strategies. When land development is frequent, land-use change should also be accounted for within an AEP spatial targeting strategy, in order to secure benefits from future land-use conversions (Newburn et al., 2005, 2006).

The efficiency of AEP targeting is highly dependent upon the correlation between costs and benefits. In this paper, we argue that this is likely to be the case in urbaninfluenced areas and that this correlation is positive, meaning that parcels of land that need the most regulations are also the most expensive ones. We propose a theoretical analysis of the interplay between urban development and agri-environmental policies. At the rural-urban fringe, farmland is more expensive because it capitalizes the option value of future land development (Capozza \& Helsley, 1989). This has consequences in terms of farming systems. Close to cities, farmland is substituted by non-land input: 11 and farming is more intensive (Beckmann, 1972, Heimlich \& Barnard, 1992; Cavailhès \& Wavresky, 2007). Many ecosystem services such as open spaces, aesthetic and cultural landscapes, ground and surface water quality are by-products of farming (Hodge, 2008). These ecosystem services may be in jeopardy near cities. Further away, farming is more extensive and agriculture produces more positive, and less negative, externalities. This spatial distribution of farming externalities also influences residential development which, in turn, modifies ecosystems. Irwin \& Bockstael (2004) have shown that land conservation policies that aim to preserve landscape and natural amenities, have an indirect side-effect in terms of the development of surrounding parcels of land. These results were also supported by Roe et al. (2004) using a conjoint analysis, and Towe (2010) and Geniaux \& Napoleone (2011), respectively, studying US and European cases using a propensity score matching method. Consequently, in our approach, AEPs may affect both farming (directly) and urban development (indirectly) and the net effects of AEPs on ecosystems is undetermined.

We built a model of a monocentric city where this interplay is made explicit. Existing urban economics models assume that amenities are either exogenous (Brueckner et al., 1999; Wu \& Plantinga, 2003; $\mathrm{Wu}, 2006$ ) or proportional to agricultural land share (Cavailhès et al. 2004, Bento et al., 2011). We modify these models by allowing the level of amenities to vary spatially with farmers' behaviour. In this endogenous setting, farming is more intensive and more polluting close to the city. We then introduce an AEP which is spatially targeted to protect a given watershed in the urban-influenced area. The implementation of the AEP depends on its adoption by farmers, which in turn depends on the opportunity cost of the land. When adopted, the AEP enables water

\footnotetext{
${ }^{1}$ Gears, chemicals, pesticides, etc.
} 
pollution from agriculture in the watershed to be regulated. However, it also increases the attractiveness of the watershed for residential development. Inevitably, and in accordance with empirical findings by Hascic \& Wu (2006) and Atasoy et al. (2006), the subsequent urban development lowers the environmental efficiency of the AEP. Thus, our model is in line with land use models and empirical evidence developed by Newburn et al. (2006) and Langpap et al. (2008). We provide a rigorous framework with which to analyse these policies in an urban setting. Contrary to Wu \& Irwin (2008), who provide an insightful analysis of the dynamic of a city, our approach is static, focusing on the AEP effects. We believe that our analysis is of particular importance to European countries for two reasons. First, AEPs are poorly targeted in Europe (Uthes et al. , 2010). While the law offers the opportunity for Member States to target benefits and cost: 2 , most European agri-environmental policy is focused on Habitat Protection Zones (Natura 2000) and Nitrate Pollution Vulnerable Zones designated by local (subnational) authorities. With the exception of a few specific cases (Kuhfuss et al., 2012), AEPs in Europe are not cost-benefit targeted. Secondly, European countries are densely populated and urban sprawl is an important concern (EEA, 2006). The remainder of the paper is as follows. In the first section, we develop a static monocentric model of an urban area with an AEP. In the second section we present a numerical application of the model. We discuss the policy implications of our findings in the final section, and conclude by evoking some ideas for future work.

\section{A model of location decision}

This section develops a model that conforms to the basic assumptions of the monocentric city model, including an exogenously determined central business district (CBD) to which households commute for employment. Households have identical incomes and preferences, and commuting costs depend on the distance between the residential location and the CBD. Land developers have identical technologies, and the market for residential development is competitive. The model assumes a thünenian organisation of suburban agriculture, so that farmers' behaviour is influenced by the city.

The landscape is represented by a cartesian coordinate plane $\mathbb{R}^{2}$, with the CBD located at $(0,0)$ and the horizontal and vertical axes representing the West-East and North-South directions, respectively. The distance between the CBD and any residential site located at $(u, v)$ is given by $x=\sqrt{\left(u^{2}+v^{2}\right)}$, which together with the angle of incidence $\theta$ also determines the location of agents, where $(u, v)=(x \cos \theta, x \sin \theta)$. The landscape is characterised by an area-featured amenity source such as a lake. All residential sites are differentiated by their proximity to this lake. Farmers located within the lake's watershed produce a residual pollution that affects the quality of amenities

\footnotetext{
${ }^{2}$ Art. 39-4 of the European Council Regulation n ${ }^{\circ} 1698 / 2005$
} 
provided by the lake.

\subsection{The household location decision}

Households make a trade-off between accessibility to the CBD and land consumption. Each household chooses a combination of residential space $q_{h}$, location $(u, v)$, and a numeraire non-housing good $s$ to maximise their utility subject to the budget constraint $w=r(u, v) q_{h}+s+\tau x$; where $w$ is the gross household income, $\tau$ is the round-trip commuting cost per kilometre and $r(u, v)$ is the housing rent at $(u, v)$. Households derive utility from the amenities $a(u, v)$ provided by the lake ecosystem (i.e. scenic lake views, fishing, recreational activities, etc).

As indicated by numerous hedonic studies on property values, the level of amenity at each location in the landscape depends on its distance from the source of the amenity. Let $a_{L}$ be the maximum level of amenity provided close to the lake $\left(u_{L}, v_{L}\right)$ and $z$ be the distance between the household's location $(u, v)$ and the lake. The level of natural amenity at any location $(u, v)$ is given by:

$$
a(u, v)=1+a_{L} e^{-\eta z}
$$

where $\eta$ is the decreasing rate of amenity as distance from the lake increases and 1 is the level of amenity at locations that are distant from the lake.

The lake is subject to pollution produced both by farms and developed parcels of land, when they are located within the lake's watershed. The total flow of pollution that reaches the lake reduces the level of amenities that the lake ecosystem provides. Therefore, the maximum level of lake amenities can be written as

$$
a_{L}=a_{0}-E(W)
$$

where $a_{0}$ is the original level of lake amenities (without pollution). The specification of the total flow of pollution $E(W)$ depends on the farmers' behaviour, discussed in section 2.4, and on the amount of urbanised land within the watershed.

The household utility function is assumed to be a Cobb-Douglas: $U\left(q_{h}, s, a(u, v)\right)=$ $q_{h}^{\beta} s^{1-\beta} a(u, v)^{\gamma}$ where $0<\beta<1$ and $\gamma>0$. The first-order conditions for the utility maximisation problem define the optimal choice of housing space and non-housing space at any location:

$$
\begin{gathered}
s^{*}(u, v)=(1-\beta)(w-\tau x) \\
q_{h}^{*}(u, v)=\frac{\beta(w-\tau x)}{r^{*}(u, v)}
\end{gathered}
$$

(3) shows that expenditure on the numeraire good decreases by $(1-\beta) \tau$ with each unit of distance $x$ from the CBD. Using (1), we can derive the houshold bid-rent function: 


$$
r^{*}(u, v)=\left[\frac{\beta^{\beta}(1-\beta)^{1-\beta}(w-\tau x)}{\bar{V}}\right]^{\frac{1}{\beta}}\left(1+a_{L} e^{-\eta z}\right)^{\frac{\gamma}{\beta}}
$$

The bid-rent function (5) corresponds to a household's maximum willingness to pay for housing at location $(u, v)$. At equilibrium, households are indifferent to where they locate because their equilibrium level of utility is the same at each location and exogenous from the perspective of an open city. In a case where there are no amenities, the bid-rent function would strictly decrease with distance to the CBD. However, with $a_{L} e^{-\eta z}>0$, households may be willing to pay more for a desirable location than for proximity to their place of work.

\subsection{Developers' decision}

Developers produce housing goods under constant return to scale in a competitive market, by converting agricultural land into residential use. They choose the location $(u, v)$ and housing density $d(u, v)$, maximising their profit function $\pi_{d}(u, v)=$ $r^{*}(u, v) d(u, v)-r_{d}(u, v)-c(d(u, v))$, where $r^{*}(u, v)$ is the rent paid by households, $r_{d}(u, v)$ is the land price paid by developers at the location $(u, v)$, and $c(d(u, v))$ is a technical and labour cost function depending on the chosen housing density. The developer's cost function is specified as follows: $c(d)=d(u, v)^{\delta}$ where $\delta>0$. Note that developers have no preferences regarding the development location. First order conditions allow us to define the optimal housing density distribution:

$$
d^{*}(u, v)=\left(\frac{r^{*}(u, v)}{\delta}\right)^{\frac{1}{\delta-1}}
$$

Competition drives profits to zero, so that we derive the following developers' bid-price for a parcel of land located at $(u, v)$ :

$$
r_{d}^{*}(u, v)=(1-\delta)\left(\frac{r^{*}(u, v)}{\delta}\right)^{\frac{\delta}{\delta-1}}
$$

\subsection{The farmers' behaviour}

Farmers produce a level of agricultural output per hectare $y$ and sell it at the CBD with transport costs $t$ per unit of distance. The production function $y=f(k,(u, v))$ is increasing and concave and has constant returns to scale. $k(u, v)$ is the level of non-land inputs per unit of land used by farmers at location $(u, v)$ and represents the intensity of farming. The prices of crops and inputs, respectively $p$ and $p_{k}$, are taken as given and the land rent at $(u, v)$ is $r_{a}(u, v)$. The agricultural production function is assumed to be a Cobb-Douglas: $y=A k^{\alpha}$ with $A>0$ and $0<\alpha<1$. In the absence of any public 
policy, the farmer's program is given by:

$$
\max _{k} \pi_{a}(k,(u, v))=\max _{k}(p-t x) f(k(u, v))-p_{k} k(u, v)-r_{a}(u, v)
$$

First-order conditions allow us to determine the level of non-land inputs used by farmers at distance $x$ from the CBD:

$$
k^{*}(u, v)=\left(\frac{\alpha A(p-t x)}{p_{k}}\right)^{1 / 1-\alpha}
$$

$k^{*}(u, v)$ is a monotonous decreasing function of distance to the CBD. Close to the city, farms tend to be intensive, characterised by a relatively high level of non-land inputs. Further away from the city, farms progressively become more extensive, as $k$ falls. This spatial variation of $k$ is consistent with many empirical observations (Katzman, 1974 , Heimlich \& Barnard, 1992; Cavailhès \& Wavresky, 2007).

Competition drives farmers' profits to zero, so that we can derive their bid-rent function at any location $(u, v)$ :

$$
r_{a}^{*}(u, v)=(p-t x)^{\frac{1}{1-\alpha}} A\left(\frac{\alpha A}{p_{k}}\right)^{\frac{\alpha}{1-\alpha}}(1-\alpha)
$$

From (10), we derive that $\partial r_{a}^{*} / \partial x<0$, meaning that $r_{a}^{*}(u, v)$ is a decreasing function of distance. This negative bid-rent gradient is due to the Thünenian behaviour, supported by empirical evidence (Plantinga et al., 2002, Cavailhès \& Wavresky, 2003 Livanis et al., 2006; $\mathrm{Wu} \& \mathrm{Lin}, 2010$ ). We assume that from a distance $\underline{x}$, suburban agriculture stops in favour of exporting farming, preserved from any urban influence, not prone to any land-use competition, and characterised by an exogenous agricultural rent $\underline{r_{a}}$. Land being allocated to the highest bidder, $\underline{x}$ is reached when: $r_{a}^{*}(\underline{x})=\underline{r}_{a}$.

\subsection{Lake pollution}

We assume that farms located within the lake's watershed $(W)$ generate pollution (i.e. sediments and pesticide run-off ). Part of this pollution ends up in the lake, and the rest is absorbed naturally as it is transported to the lake. Let $\phi_{a}$ be the rate of pollution generated per unit of farm intensity $k$ and $\lambda_{a}$ be the natural absorption coefficient, depending on the bio-physical characteristics of the soil (eg. texture, porosity, slope, amount of organic matter). Therefore, the net flow of agricultural pollution affecting the lake is given by:

$$
E_{a}(W)=\iint_{W} \phi_{a} k^{*}(u, v) e^{-\lambda_{a} z} d u d v
$$

where $z$ is the distance between the farm and the lake. One can reasonably assume that farms located outside the watershed have no polluting effects on the lake. In addition, 
as in Wu \& Irwin (2008) and Chen et al. (2009), we consider that developed land also pollutes the lake. The flow of residential pollution that reaches the lake depends on the housing density of the developed area within the watershed. It is given by:

$$
E_{d}(W)=\iint_{W} \phi_{d} d^{*}(u, v) e^{-\lambda_{d} z} d u d v
$$

where $d^{*}(u, v)$ is given by (6) and $\lambda_{d}$ represents the decreasing rate of pollution with distance from the lake.

Thus, the total flow of pollution that reaches the lake is:

$$
E(W)=E_{a}(W)+E_{d}(W)
$$

\subsection{Implementation of a spatially targeted agri-environmental policy (AEP)}

The government introduces an agri-environmental policy (AEP) aimed at reducing pollution of the lake by agriculture. The AEP only targets farmers settled within the lake's watershed. This policy consists of a voluntary contract with farmers. Contracting farmers reduce their use of non-land inputs $k$ down to a fixed non-land inputs target level $\widetilde{k}$. In return, participating farmers are granted a uniform subsidy $\sigma$ in euros per hectare. The policy is fully described by the couple $(\sigma, \widetilde{k})$. Participating farmers' profit function is given by:

$$
\begin{gathered}
\max _{k}(p-t x) f(k(u, v))-p_{k} k(u, v)-r_{a}(u, v)+\sigma \\
\text { s.t. } k(u, v) \leq \widetilde{k} \text { and }(u, v) \in W
\end{gathered}
$$

There is a critical distance from which all farmers already comply with the maximum level of non-land inputs $\widetilde{k}$ decided by local authorities. This critical distance is given by $k^{*}(\widetilde{x})=\widetilde{k}$, from which we derive:

$$
\widetilde{x}=\frac{1}{t}\left(p-\frac{p_{k}}{\alpha A} \widetilde{k}^{1-\alpha}\right)
$$

A rational farmer agrees to participate if the subsidy compensates for his loss of profit. The condition for a farmer to participate can be written:

$$
(p-t x) f\left(k^{*}\right)-p_{k} k^{*}-r_{a} \leq(p-t x) A \widetilde{k}^{\alpha}-p_{k} \widetilde{k}-r_{a}+\sigma
$$

There is a location $\widetilde{x}^{\prime}$, from which farmers agree to participate in the program, although they have to change their practices. $\widetilde{x}^{\prime}$ solves:

$$
A\left(\frac{\alpha A}{p_{k}}\right)^{\frac{\alpha}{1-\alpha}}(1-\alpha)\left(p-t \widetilde{x}^{\prime}\right)^{1 / 1-\alpha}-A \widetilde{k}^{\alpha}\left(p-t \widetilde{x}^{\prime}\right)+p_{k} \widetilde{k}-\sigma=0
$$


Empirical studies confirm that the probability to participate in agricultural land preservation programs increases with the distance between the farm and the nearest city (Lynch \& Lovell, 2003, Duke, 2004)

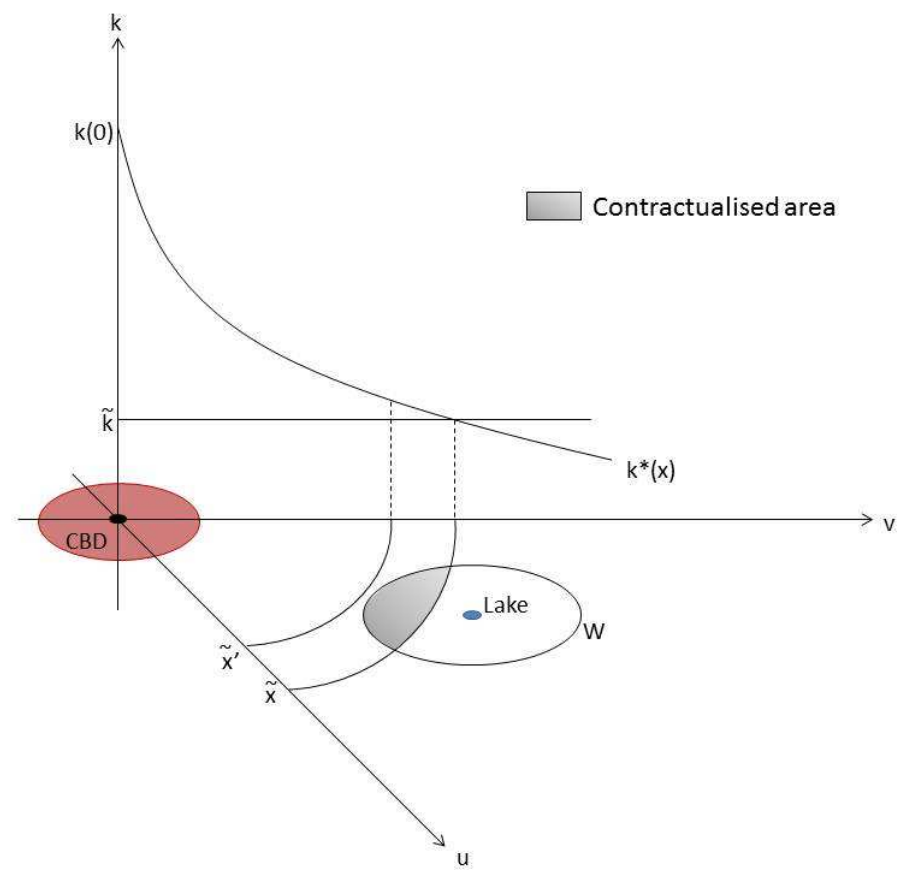

Figure 1: Agricultural intensity gradient and decision to adopt the policy

We suppose that there are no information asymmetries between farmers and the government, and that administrative transactions are without cost. Thereby, the government has a perfect foresight of farmers' input use at any location. Figure 1 shows how the agricultural intensity is distributed across space, and which farmers, depending on their location, are likely to adopt the measure. Farmers located further than $\widetilde{x}$ are not granted any subsidy, although they already comply with input restrictions. Farmers located between the city and $\widetilde{x}^{\prime}$ do not adopt the measures as the subsidy does not compensate them for their loss of profit. Farmers between $\widetilde{x}$ and $\widetilde{x}^{\prime}$ within the lake watershed agree to adopt the measure and are granted the subsidy.

The spatial distribution of farming intensity is then given by:

$$
k(u, v)=\left\{\begin{array}{lr}
\widetilde{k}, & \text { if } x \in\left[\widetilde{x}^{\prime}, \widetilde{x}\right] \text { and }(u, v) \in W \\
k^{*}, & \text { otherwise }
\end{array}\right.
$$

Thus by choosing $\widetilde{k}$, the government determines the adoption distance $\widetilde{x}^{\prime}$ and by choosing $\sigma$, sets the depth $\left(\widetilde{x}-\widetilde{x}^{\prime}\right)$ of the regulated area. By using $(10)$ and $(18)$, we derive the farmers' bid function: 


$$
r_{a}^{*}(u, v)=\left\{\begin{array}{cr}
(p-t x) A \widetilde{k}^{\alpha}-p_{k} \widetilde{k}+\sigma, & \text { if } x \in\left[\widetilde{x}^{\prime}, \widetilde{x}\right] \text { and }(u, v) \in W \\
(p-t x)^{\frac{1}{1-\alpha}} A\left(\frac{\alpha A}{p_{k}}\right)^{\frac{\alpha}{1-\alpha}}(1-\alpha), & \text { otherwise }
\end{array}\right.
$$

\subsection{Spatial equilibrium}

Having derived the behavioural function for households, developers and farmers, we now characterise spatial equilibrium for land development. Six conditions combining households', farmers' and developers' decisions determine the spatial equilibrium.

1. Housing prices are bid up until no household has any incentive to move. This condition is satisfied when housing prices are represented by (5) since the household's bid function is the maximum willingness to pay for housing.

2. At each location the price households are willing to pay for housing equals the price developers are willing to accept for housing $\left(r(u, v)=r^{*}(u, v)\right)$.

3. Land prices are bid up until profits equal zero everywhere and developers are indifferent to the location of development.

4. The number of households at any location $n(u, v)$ equals the development density divided by floor space per household : $n(u, v)=d^{*}(u, v) / q^{*}(u, v)$. Land will be developed if the developer's bid price for land exceeds the agricultural rent 19. Thus the developed area is $D=\left\{(u, v) \mid r_{d}^{*}(u, v) \geq r_{a}^{*}(u, v)\right\}$ and the total number of households $(N)$ in the city is given by:

$$
\iint_{D} \frac{d^{*}(u, v)}{q_{h}^{*}(u, v)} d u d v=N
$$

5. The boundaries of the developed area are given by a set of points $(\bar{u}, \bar{v})$, defined by: $r_{d}^{*}(\bar{u}, \bar{v})=r_{a}^{*}(\bar{u}, \bar{v})$.

6. The level of pollution that reaches the lake at equilibrium $E^{*}(W)$ is given by (13) and depends on the developed element of the watershed, and on the proportion that is left to agricultural activity.

The lake watershed $W$ is defined by $W=\left\{(u, v) \mid\left(u-u_{L}\right)^{2}+\left(v-v_{L}\right)^{2} \leq z_{W}^{2}\right\}$, where $\left(u_{L}, v_{L}\right)$ denotes the coordinates of the lake and $z_{W}$ is the radius of the watershed. The agricultural area within the lake watershed is defined by the set $W_{a}=W-(D \cap W)$; that is the watershed area minus its developed part. The boundaries of the agricultural area influenced by the city are determined by the level of the exogenous agricultural rent, when $r_{a}^{*}(\underline{u}, \underline{v})=\underline{r_{a}}$. We choose only to focus on cases where the targeted ecosystem is located within the area influenced by the city. In other words, we assume that $z_{L}+z_{W}<$ 
$\underline{x}$, meaning that the lake and its watershed are fully incorporated within the area under the influence of the city. We do not study the case where exporting independant farming is responsible for polluting the lake.

\section{Simulation results}

\subsection{Parameter values}

In this section, we discuss the parameter values used in our benchmark simulations. The households' income level and the proportion of their expenditure dedicated to housing were set using data from the INSEE (French National Institute of Statistics and Economic Studies) database ${ }^{3}$. Transport costs were derived from the French Internal Revenue Service estimating commuting costs at around $0.4 € / \mathrm{km}$. Finally, the equilibrium level of utility was set so that the urban rent at the CBD is plausible. $\bar{V}=10,000$ leads to $r^{*}(0,0)=12.5 € / \mathrm{m}^{2} /$ year. With regard to the developer's parameter, we set $\delta=4 / 3$ as in $\mathrm{Wu}(2006)$.

Agricultural parameters such as the elasticity of production factor $k$ and the ratio between output price and non-land input price were set from the Farm Accountancy Data Network 4 . The exogenous exporting farm rent is derived from the average agricultural land price given by the Agreste (French institute of agricultural statistics) $)^{5}$ at around $5,000 € / h a$ in France and assuming a discount rate of 0.05. Transport costs for farmers $(t)$ and pollution parameters $\left(\phi_{a}, \phi_{d}, \lambda_{a}\right.$ and $\left.\lambda_{d}\right)$ were set to $a d-h o c$ values.

Parameter values are shown in Table 1. Households preferences for amenities $(\gamma)$ and the distance between the lake and the CBD $\left(z_{L}\right)$ are not specified as we discuss their impact in the next section.

\subsection{Amenity location and urban development}

We now present the equilibrium spatial pattern of development when no AEP is implemented. Therefore, we set $\sigma=0$ and $\tilde{k}=0$ for the moment.

Figure 2 depicts four different urban configurations that can be obtained depending on two key parameters : the distance between the lake and the CBD $\left(z_{L}\right)$ and households preferences for amenities $(\gamma)$. We present the equilibrium urban configuration for $z_{L}=$ $(40,50)$ and $\gamma=(0.05,0.12)$. The developed area can have the following patterns. First, the lake has no influence on the city. This occurs where there is a large enough distance between the lake and the $\operatorname{CBD}\left(z_{L}=50\right)$ and preferences for amenities are low $(\gamma=0.05)$. The developed area has the characteristics of a symmetrical monocentric city (Figure $2 \mathrm{a}$ ). Secondly, the developed shape is slightly distorted by the presence of the

\footnotetext{
${ }^{3}$ http://www.insee.fr/fr/themes/ (accessed: May 22nd 2012)

${ }^{4} \mathrm{http}: / /$ ec.europa.eu/agriculture/rica/database/database_en.cfm (accessed: January 18th 2012)

${ }^{5}$ http://agreste.agriculture.gouv.fr/ (accessed: August 3rd 2012)
} 


\begin{tabular}{lll}
\hline Description variable & Value \\
\hline$w$ & household income & $33,000 € /$ household \\
$\tau$ & household transport costs & $450 € / \mathrm{km} /$ year/household \\
$\beta$ & proportion of expenses dedicated to housing & 0.25 \\
$\bar{V}$ & equilibrium utility level & 10,000 \\
$p$ & agricutural goods price & $2.62 € /$ output unit \\
$p_{k}$ & non-land inputs price & $1 € /$ non-land input unit \\
$t$ & farmers transport costs & $0.02 € / \mathrm{km} /$ output unit \\
$A$ & technical constant & 1 \\
$\alpha$ & elasticity of production factor $k$ & 0.8 \\
$r_{a}$ & exogenous exporting farm rent & $250 € /$ ha/year \\
$\phi_{a}$ & rate of pollution generated per unit of farm intensity & 0.50 \\
$\phi_{d}$ & rate of pollution generated per unit of household density & 0.01 \\
$\lambda_{a}$ & natural absorption coefficient of agricultural pollution & 0.3 \\
$\lambda_{d}$ & natural absorption coefficient of residential pollution & 0.3 \\
$z_{W}$ & radius of the watershed & $10 \mathrm{~km}$ \\
$a_{0}$ & original level of amenities provided by the lake & 300 \\
$\eta$ & decreasing rate of amenities with distance away from the lake & 0.3 \\
$\delta$ & ratio of housing value to the non-land construction costs & $4 / 3$ \\
\hline
\end{tabular}

Table 1: Parameter value and signification

lake. This is the case when the lake is located nearer to the city $\left(z_{L}=40\right)$. Household preferences for amenities are not sufficiently high to drive households to move right next to the lake $(\gamma=0.05)$. However, the flow of amenities provided by a more accessible lake makes the city extend in its direction (Figure 2b). Thirdly, we can observe a fragmented land development pattern. In Figure 20, the lake is at a substantial distance from the $\operatorname{CBD}\left(z_{L}=50\right)$ but, as household preferences are higher than in case (a), some households decide to move right next to the lake, leading to the existence of two distinct developed areas. Finally, the last case is the one where we observe one unique area embracing both the CBD and the lake (Figure 2 $\mathrm{d}$ ). In this case, the lake is close enough to the city $\left(z_{L}=40\right)$ and preferences are higher $(\gamma=0.12)$.

\subsection{Model sensitivity to residential pollution parameter $\left(\phi_{d}\right)$}

After highlighting the importance of the amenity's characteristics - i.e. the location of the amenity source and how it is valued by households - in the pattern of land development, we analyse the sensitivity of the model with regard to the residential pollution effect $\left(\phi_{d}\right)$ in the case of benchmark (c) $\left(z_{L}=50\right.$ and $\left.\gamma=0.12\right)$. Figure 3 a depicts the size of the total developed area and of the disconnected developed area only, at different levels of impact from residential pollution. As $\phi_{d}$ increases, land development decreases. This is due to the negative impact pollution has on the level of amenities provided by the lake. The equilibrium is reached when the development of another parcel of land would lead to a lower level of amenity, so that no more households would 

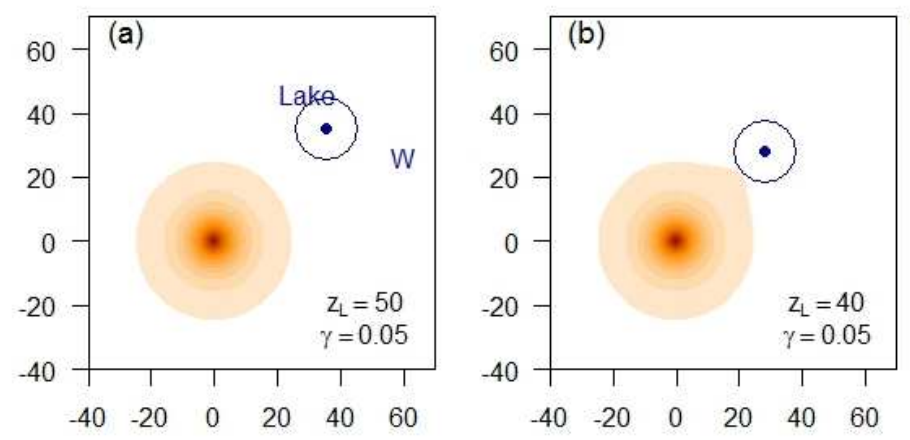

Housing density

( $\mathrm{m}^{2}$ per unit of surface)
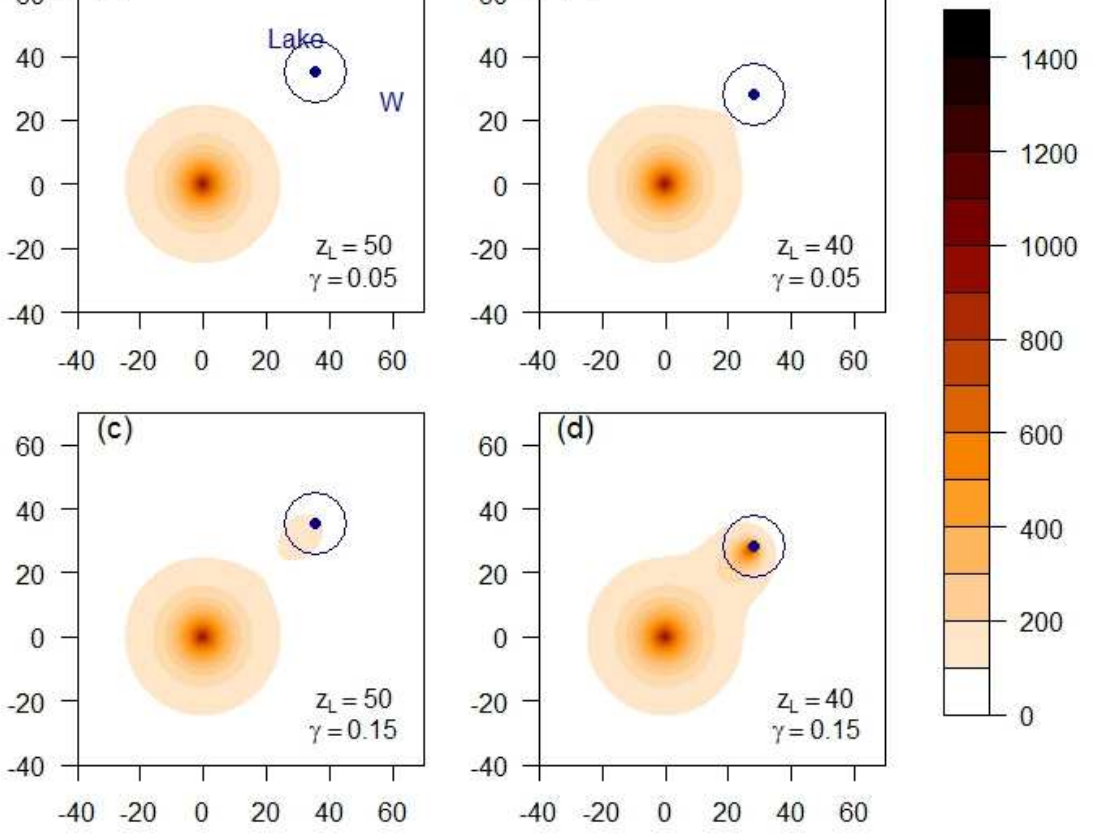

Figure 2: Urban development configurations

be motivated to relocate to the area. Figure 3 a also shows that the variation in the size of the total developed area can largely be explained by the variation in the size of the disconnected part of the city alone. In terms of pollution, Figure $3 \mathrm{~b}$ shows how the total flow of pollution reaching the lake increases with $\phi_{d}$. Obviously, residential pollution is higher when $\phi_{d}$ increases. Note however that the level of agricultural pollution is also influenced by the residential pollution effect. A higher $\phi_{d}$ means a smaller developed area, and therefore more agricultural land which is also likely to pollute the lake.

\subsection{Impacts of a spatially targeted agri-environmental policy}

Simulations of our spatial city model enable us to investigate the effects of a spatially targeted AEP on urban development. A whole set of simulations were undertaken for different combinations of $(\sigma, \tilde{k})$, characterising different spatially targeted AEPs implemented on our benchmark configurations depicted in Section 3.2 .

In the case of benchmark (a), the lake is located at a substantial distance from the city and household preferences for amenities are low $\left(z_{L}=50\right.$ and $\left.\gamma=0.05\right)$, so that the lake has no influence on households or therefore on the shape of the developed area. We observe no significant side effects of the spatially targeted AEP in terms of urban development.

In the case of benchmark (d), as the surroundings of the lake are already developed 

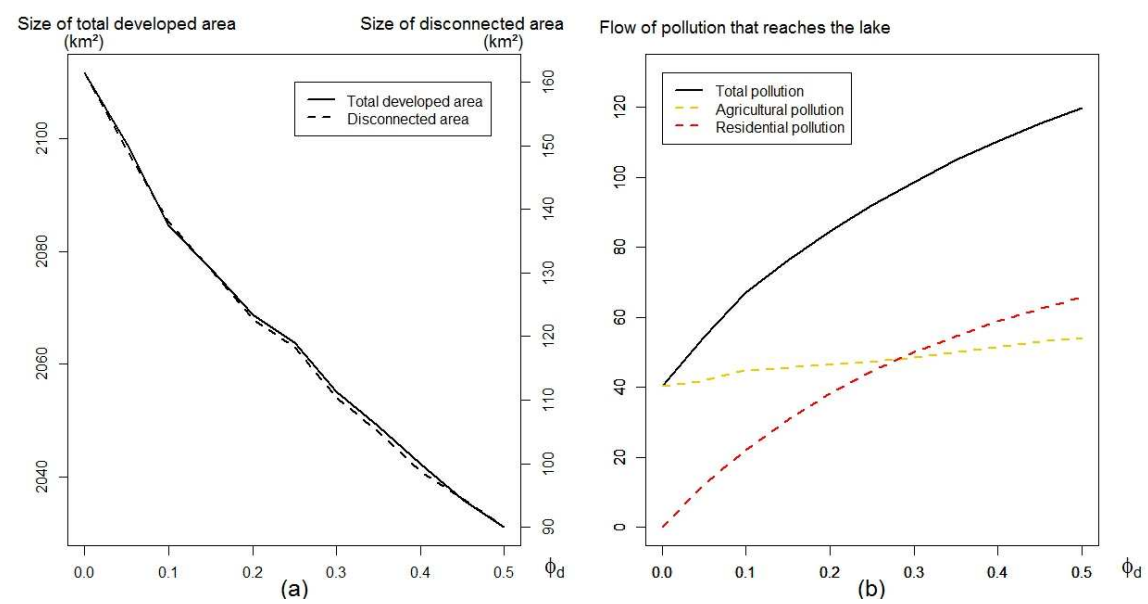

Figure 3: Sensitivity of the size of the developed area (a) and the level of pollution (b) regarding $\phi_{d}$. Benchmark (c).

to a large extent, the variations in the size of the developed area, due to the introduction of the spatially targeted AEP, remain relatively low.

However, for benchmarks (b) and (c), we observe that the spatially targeted AEP we introduce is not completely neutral in terms of urban development, depending on different elements. The results for benchmarks (b) and (c) are presented in the form of diagrams (Figure 4), allowing us to anticipate what the impact of the introduction of any $(\sigma, \tilde{k})$ could be in terms of variation in the size of the developed area.

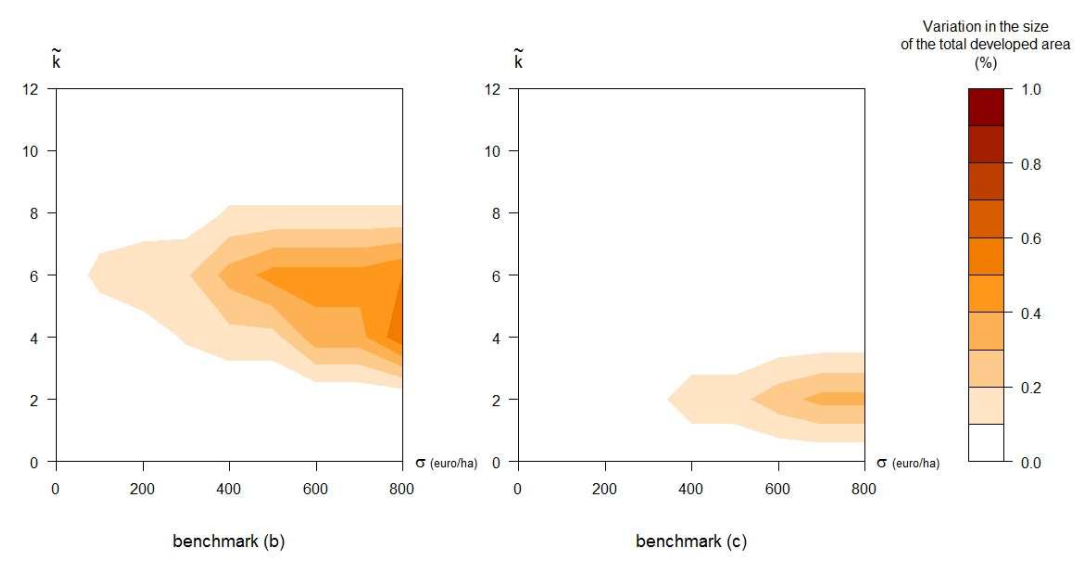

Figure 4: Variation in the size of the developed area following the introduction of a spatially targeted AEP

In Figure 4, we observe that, for some given $(\sigma, \tilde{k})$, the total developed area increases up to $1 \%$ for benchmark (b) and $0.4 \%$ for benchmark (c). The economic mechanism explaining this effect is that, for a given $(\sigma, \tilde{k})$, the flow of agricultural pollution reaching the lake can be significantly reduced, thereby providing a higher level of amenities. 
Households may wish to pay more to be located near to the lake than they would have without the policy. An increase in household bid-rent makes developers raise their bidprice for land to the detriment of farmers. This mechanism logically leads to an increase in the developed area between the city and the lake. Obviously, whether or not the implementation of the policy has a positive impact on the size of the developed area is highly dependent upon the extent of the subsidy and on the location of the adopting area determined by local authorities via the decision of $(\sigma, \tilde{k})$. Therefore, the choice of policy is crucial in terms of the extent of the side effects that we identified. Furthermore, the budget aspect needs to be taken into consideration as the cost of the policy may vary depending on the choice of $(\sigma, \tilde{k})$.

\section{Policy implications}

\subsection{Policy design and budget aspects}

As indicated in the previous section, the effects of a spatially targeted AEP in terms of undesirable land development largely depend on the extent to which the policy is adopted by farmers, and therefore on the combinations of $(\sigma, \tilde{k})$ decided by policy authorities. We have not taken into consideration the impacts of the policy in terms of budget until now.

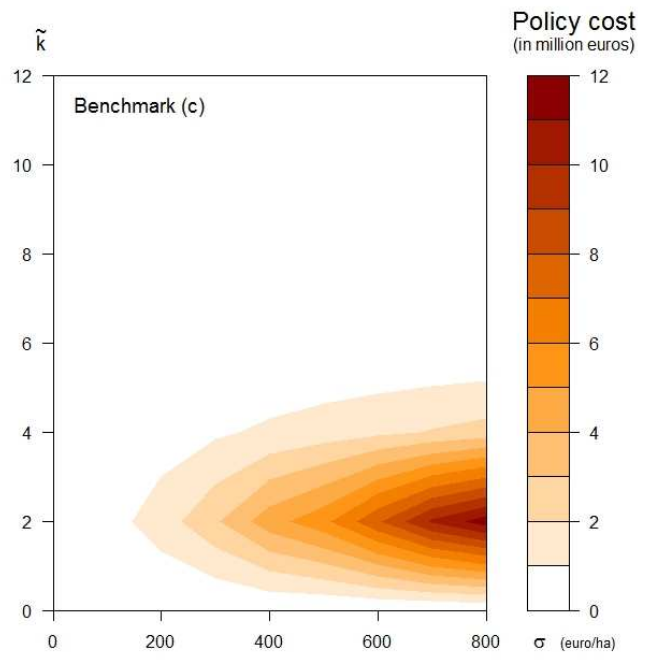

Figure 5: Policy cost for different combinations of $(\sigma, \tilde{k})$ from benchmark (c)

Figure 5 depicts the cost of different combinations of $(\sigma, \tilde{k})$ implemented on benchmark (c) ${ }^{6}$. We observe that the policy cost varies widely. The minimum cost $(0 €)$ is attained when none of the farmers located within the watershed have any interest in

\footnotetext{
${ }^{6}$ In our simulations, we assume that $30 \%$ of agricultural land is dedicated to non-agricultural uses (i.e. roads, farm buildings...)
} 
adopting the contract. This occurs when the maximum level of non-land inputs to be used $(\tilde{k})$ is too restrictive and the subsidy $(\sigma)$ is not high enough to compensate them for the reduction in profit. Conversely, it also occurs when the maximum level of non-land inputs is not restrictive enough, as this prevents farmers from adopting the AEP as they would not actually change their existing practices.

The cost increases rapidly as farmers start to adopt the contract. This corresponds to the fact that the non-land inputs limit is restrictive enough to ensure that farmers do change their practices, and that the level of subsidy compensates them for lost profits.

Obviously for a given $(\sigma, \tilde{k})$, the budget may also change depending on the size of the watershed and on the distance between the lake and the $\mathrm{CBD}$, as farmers have varying land opportunity costs depending on their location. A larger watershed means a higher policy cost, as a greater number of farmers would have the opportunity to adopt the contract. Similarly, if the lake is at a distance where surrounding farmers are likely to be interested in adopting the contract, the anticipated budget will be higher. However, if the lake is either too close to the city, or too far from it, the budget will decrease as farmers will be unlikely to adopt the AEP as their practices will be either too intensive or the reverse.

In the case of benchmark (c), to ensure that absolutely all farmers located within the watershed agree to adopt the AEP, local authorities must implement a policy characterised by $\tilde{k}=1.8$ and $\sigma=4,500 € /$ ha, representing a total cost of more than 50 million euros. In reality, the level of a subsidy hardly ever exceeds $800 € /$ ha 7 . Making all farmers adopt the AEP would be relatively expensive. Local authorities therefore need to choose who to target within the watershed itself.

In the following section, we compare the impacts of different combinations of the spatially targeted AEP, at constant budget.

\subsection{Double spatial targeting of the policy}

We assume that local authorities have to design their spatially targeted AEP with a fixed exogenous budget of 2.2 million euros 8 . Their perfect foresight in terms of farmers' behaviour at any location allows them to determine different combinations of $(\sigma, \tilde{k})$ to meet their budget. Formally, by choosing a given $(\sigma, \tilde{k})$, they also decide which area is likely to adopt the measure. We call this double spatial targeting. It means that authorities choose a first target, which is the watershed. In addition, their choice of $(\sigma, \tilde{k})$ to meet their budget will define a second target area within the watershed. In

\footnotetext{
${ }^{7}$ In France, the detailed levels of subsidies for AEPs implemented in any region are available at http://agriculture.gouv.fr/pac-developpement-rural-feader (accessed: December 11th 2012), through the official Regional Document on Regional Development (Document Régional de Développement Rural 200\%2013)

${ }^{8}$ In the French Region Pays de la Loire, nearly 40 million euros are dedicated to the implementation of spatially targeted AEPs for the period 2010-2015 (Regional Document on Regional Development, Pays de la Loire)
} 
this section, we show how the impacts of the AEP may differ depending on this second spatial targeting.

We distinguish three specific cases depicted in Figure6. Case A denotes the situation where the choice of $(\sigma, \tilde{k})$ is of interest to farmers located in the North-Western part of the watershed. Case $\mathrm{C}$ consists of a choice of $(\sigma, \tilde{k})$ likely to interest farmers located in the South-Eastern part of the watershed, nearer to the city and thus more exposed to competition for residential land use. Finally, case B is an intermediate situation where farmers who are likely to adopt the contract are located in the middle of the watershed.

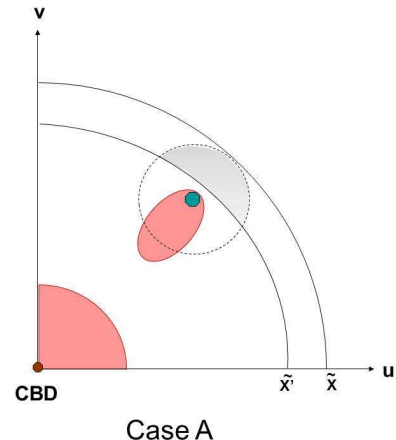

Case A

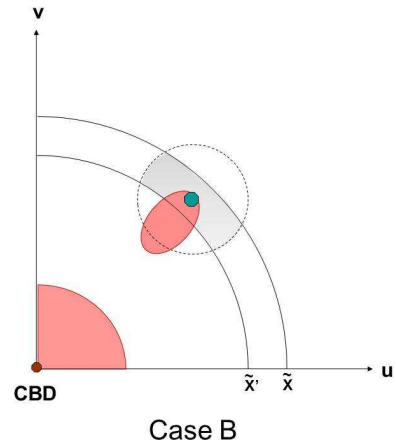

Case B

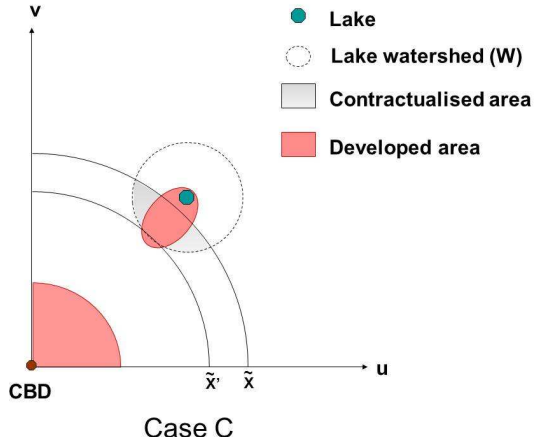

Case C

Figure 6: Double spatial targeting

In Table 2, we present the effects of the policy in terms of the pollution level and urban development side effects, from benchmark (c) and under three combinations of $(\sigma, \tilde{k})$ each one representing cases A, B and C respectively (see Figure 6), and all of them satisfying the fixed budget of 2.2 million euros.

With an identical budget, and depending on the second spatial targeting of authorities, we observe different effects of the policy (Table 2). We first consider the situation where residential development has no polluting effect. In case A, farmers who are likely to adopt the policy are located in the North-Western part of the watershed. In terms of pollution reduction, this policy has a positive impact as the equilibrium flow of pollution that reaches the lake decreases by nearly $14 \%$, compared to a case where no policy is implemented. However, we observe the occurrence of an undesirable side effect in terms of development. The disconnected developed area increases by $3.41 \%$, which, as explained before, is due to the improvement in the level of amenity induced by the policy. Conversely, in case $\mathrm{C}$, the adopting area is located nearer to the city. The implementation of the policy allows farmers to resist development, as they are granted a subsidy, thereby limiting the increase in the size of the leapfrog area. In terms of pollution reduction, the policy has a lower effect $(-2.60 \%)$. Indeed, as farmers are more intensive in this area than in case A, the policy has to be less restrictive if it targets this specific area. Between these two extreme cases, we identify an intermediate situation (case B) where the flow of pollution decreases by nearly $9 \%$ and leapfrog development increases less 
Without residential pollution $\left(\phi_{d}=0\right)$

\begin{tabular}{lc|ccc}
\hline Case & Benchmark & A & B & C \\
\hline$\sigma(€ /$ ha $)$ & 0 & 300 & 380 & 720 \\
$\tilde{k}$ & 0 & 2.2 & 3.7 & 5.2 \\
Total developed area $\left(\mathrm{km}^{2}\right)$ & $2,111.75$ & $+0.26 \%$ & $+0.17 \%$ & $+0.07 \%$ \\
Disconnected developed area $\left(\mathrm{km}^{2}\right)$ & 161.5 & $+3.41 \%$ & $+2.17 \%$ & $+0.93 \%$ \\
Total flow of pollution & 40.32 & $-13.89 \%$ & $-8.88 \%$ & $-2.60 \%$ \\
Farming pollution & 40.32 & $-13.89 \%$ & $-8.88 \%$ & $-2.60 \%$ \\
Residential pollution & - & - & - & - \\
\hline \hline
\end{tabular}

With residential pollution $\left(\phi_{d}=0.2\right)$

\begin{tabular}{lc|ccc}
\hline Case & Benchmark & A & B & C \\
\hline$\sigma(€ /$ ha) & 0 & 300 & 380 & 720 \\
$\tilde{k}$ & 0 & 2.2 & 3.7 & 5.2 \\
Total developed area $\left(\mathrm{km}^{2}\right)$ & $2,072.25$ & $+0.23 \%$ & $0.12 \%$ & $+0.05 \%$ \\
Disconnected developed area $\left(\mathrm{km}^{2}\right)$ & 126.25 & $+3.37 \%$ & $+1.58 \%$ & $+0.79 \%$ \\
Total flow of pollution & 85.43 & $-5.00 \%$ & $-3.61 \%$ & $-1.21 \%$ \\
Farming pollution & 46.28 & $-13.03 \%$ & $-8.75 \%$ & $-3.00 \%$ \\
Residential pollution & 39.15 & $+4.50 \%$ & $+2.48 \%$ & $+0.95 \%$ \\
\hline \hline
\end{tabular}

Table 2: Policy effects in terms of development and pollution at constant budget. Bench$\operatorname{mark}(\mathrm{c})$.

than in case $\mathrm{A}(+2.17 \%)$.

In a situation where residential development has a polluting effect $\left(\phi_{d}>0\right)$, the results are similar (Table 2). However, the positive impact on the size of the total developed area and the disconnected developed area is counterbalanced by the residential polluting effect (as discussed in Section 3.3). The flow of pollution reaching the lake is higher when we introduce residential pollution (here $\phi_{d}=0.2$ ), and the effects of the AEP in terms of pollution reduction are lower. This is explained by the additional developed area, creating more residential pollution than in the benchmark case $(+4.50$ $\%$ in case A), and therefore counterbalancing the decrease in agricultural pollution.

\section{Discussion and conclusion}

What are the lessons to be learned with regard to the design of spatially targeted agrienvironmental policies?

Spatially targeted AEPs are implemented to respond to specific environmental issues threatening local ecosystems. In cases where the ecosystem provides amenities valued by households when making decisions about their residential location, we highlight the potential side effects of a spatially targeted AEP in terms of suburban development. As shown in the model, the lake itself has an influence on the size and shape of the 
developed area, depending on geographical characteristics - particularly its distance to the city centre - and on households' preferences for natural amenities.

Although designed to adress ecological issues, the introduction of a spatially targeted AEP may produce unexpected side effects in terms of urban development. Depending on the restrictiveness and level of subsidy characterising the policy, we may end up in a situation where land development is significantly accentuated, or conversely, to a situation where this effect is not observed. The occurrence of additional land development can be explained by the following economic mechanism. By reducing the pollution in the ecosystem, the implementation of the policy also favours the improvement of its quality as an amenity. More households may then be encouraged to locate further from the city and nearer to the lake to enjoy this increased level of amenity. However, this mechanism is counterbalanced by the fact that, by receiving the associated subsidy, participating farmers may have the opportunity to resist developers' bids for land. The relative weight of both mechanisms depends on which farmers adopt the policy within the target area $W$. More generally, authors have highlighted that basing an AEP solely on cost or benefits criteria is less efficient than a policy based on the benefit to cost ratio (Babcock et al., 1997; Uthes et al., 2010). Following the results of our model, we therefore propose the idea of double spatial targeting, which should consider both benefits - a decrease in the level of agricultural pollution and an improvement in the level of amenity - and costs - additional urban development and residential pollution resulting from the implementation of an AEP.

The first target is the decision to direct the policy solely at potential polluters, i.e. the designation of the watershed as the target area. The second spatial target involves taking into consideration the heterogeneity of farmers' behaviour. Depending on their optimal intensity level, farmers are likely either to adopt the policy or not. Thus, the choice of subsidy and restrictiveness of the policy is crucial. Within the watershed, participating farmers can be located either in an area which is likely to be developed first or in an area relatively safe from development. If the adopting area is not likely to be developed first, the AEP should achieve its main aim to decrease the flow of pollution, leading to a high level of benefit. However, improvements in the quality of amenities might lead to competition for land in favour of developers, in the area between the lake and the city, meaning a cost in terms of undesirable residential development. If the adopting area is likely to be developed first, the effects in terms of pollution reduction might not be significant, as farmers may already be more intensive in this area, and the policy should be less restrictive to convince them to adopt. This situation leads to a low benefit in terms of agricultural pollution. On the other hand, farmers may have the opportunity to increase their bid-rent, thereby counterbalancing the undesirable side effects in terms of suburban development.

Obviously, these two cases are extreme ones. There are intermediate situations where 
the AEP could achieve its aim without creating undesirable side effects. To meet these intermediate cases, authorities must therefore carefully design their policy, anticipating the areas where farmers would be likely to adopt, and evaluating the risks in terms of suburban development.

We also highlight that, taking into account residential pollution, the additional land development following the implementation of the policy also leads to an increase in the level of residential pollution reaching the lake. Hascic \& Wu (2006) have shown that water quality can be affected both by agricultural and residential pollution, in similar proportions. Authorities should therefore have an accurate idea of how residential land use might pollute the ecosystem they wish to protect, in order to avoid generating contradictory effects.

Further research would involve using a dynamic model in which the time process would be taken into account, reflecting the irreversibility of land conversion from agricultural to residential use and the complexity of pollution transport to the lake. Indeed, flows of agricultural or residential pollution involve complicated biological and physical processes that are not captured in our simplified model, which merely deals with interactions between the lake quality and the surrounding agriculture and residential development.

\section{References}

Atasoy, M., Palmquist, R.B., \& Phaneuf, D.J. 2006. Estimating the effects of urban residential development on water quality using microdata. Journal of environmental management, 79(4), 399-408.

Babcock, B.A., Lakshminarayan, PG, Wu, J.J., \& Zilberman, D. 1997. Targeting tools for the purchase of environmental amenities. Land Economics, 73(3), 325-339.

Baylis, K., Peplow, S., Rausser, G., \& Simon, L. 2008. Agri-environmental policies in the EU and United States: A comparison. Ecological Economics, 65(4), 753-764.

Beckmann, Martin J. 1972. Von Thünen Revisited: A Neoclassical Land Use Model. The Swedish Journal of Economics, 74(1), 1-7.

Bento, A.M., Franco, S.F., \& Kaffine, D. 2011. Welfare Effects of Anti-Sprawl Policies in the Presence of Urban Decline. Agricultural and Resource Economics Review, 40(3), $439-450$.

Brueckner, Jan K., Thisse, J.F., \& Zenou, Yves. 1999. Why is central Paris rich and downtown Detroit poor?: An amenity-based theory. European Economic Review, 43(1), 91-107. 
Canton, J., De Cara, S., \& Jayet, P.A. 2009. Agri-environmental schemes: Adverse selection, information structure and delegation. Ecological Economics, 68(7), 21142121.

Capozza, D.R., \& Helsley, R.W. 1989. The fundamentals of land prices and urban growth. Journal of urban economics, 26(3), 295-306.

Cavailhès, Jean, \& Wavresky, Pierre. 2003. Urban influences on periurban farmland prices. European Review of Agricultural Economics, 30(3), 333-357.

Cavailhès, Jean, \& Wavresky, Pierre. 2007. Les effets de la proximité de la ville sur les systèmes de production agricoles. Agreste Cahiers, 2(July).

Cavailhès, Jean, Peeters, Dominique, Sékeris, Evangelos, \& Thisse, Jacques-François. 2004. The periurban city: why to live between the suburbs and the countryside. Regional Science and Urban Economics, 34(6), 681-703.

Chen, Yong, Irwin, Elena G., \& Jayaprakash, Ciriyam. 2009. Dynamic modeling of environmental amenity-driven migration with ecological feedbacks. Ecological Economics, 68(10), 2498-2510.

Choe, C., \& Fraser, I. 1999. Compliance Monitoring and Agri-Environmental Policy. Journal of agricultural economics, 50(3), 468-487.

Duke, Joshua M. 2004. Participation in agricultural land preservation programs: parcel quality and a complex policy environment. Agricultural and Resource Economics Review, 33(1), 34-49.

EEA. 2006. Urban sprawl in Europe : The ignored challenge. Report 10. European Environment Agency, Copenhagen.

Geniaux, Ghislain, \& Napoleone, Claude. 2011. aluation des effets des zonages environnementaux sur la croissance urbaine et l'activitricole. Economie et statistique.

Hascic, I., \& Wu, J.J. 2006. Land use and watershed health in the United States. Land Economics, 82(2), 214-239.

Heimlich, R.E., \& Barnard, C.H. 1992. Agricultural adaptation to urbanization: Farm types in northeast metropolitan areas. Northeastern journal of agricultural and resource economics, 21(1), 50-60.

Hodge, I. 2008. Multifunctionality in Agriculture: Evaluating the Degree of Jointness, Policy Implications. Paris: Organization for Economic Cooperation and Development. Chap. To What Extent are Environmental Externalities a Joint Product of Agriculture? Overview and Policy Implications, pages 85-118. 
Irwin, E.G., \& Bockstael, N.E. 2004. Land use externalities, open space preservation and urban sprawl. Regional science and urban economics, 34(6), 705-725.

Katzman, Martin T. 1974. The Von Thuenen Paradigm, the Industrial-Urban Hypothesis, and the Spatial Structure of Agriculture. American Journal of Agricultural Economics, 56(4), 683-696.

Kuhfuss, L., Menu, M.F., Prt, R., \& Thoyer, S. 2012. Une alternative originale pour l'allocation de contrats agro-environnementaux: l'appel à projets de l'Agence de l'eau Artois-Picardie. Pour, 97-105.

Langpap, C., Hascic, I., \& Wu, J.J. 2008. Protecting watershed ecosystems through targeted local land use policies. American Journal of Agricultural Economics, 90(3), 684-700.

Latacz-Lohmann, U., \& Van der Hamsvoort, C. 1997. Auctioning conservation contracts: a theoretical analysis and an application. American Journal of Agricultural Economics, 79(2), 407-418.

Livanis, G., Moss, C.B., Breneman, V.E., \& Nehring, R.F. 2006. Urban sprawl and farmland prices. American Journal of Agricultural Economics, 88(4), 915-929.

Lynch, Lori, \& Lovell, Sabrina J. 2003. Combining spatial and survey data to explain participation in agricultural land preservation programs. Land Economics, 79(2), 259-276.

Newburn, D., Reed, S., Berck, P., \& Merenlender, A. 2005. Economics and LandUse Change in Prioritizing Private Land Conservation. Conservation Biology, 19(5), 1411-1420.

Newburn, D.A., Berck, P., \& Merenlender, A.M. 2006. Habitat and open space at risk of land-use conversion: targeting strategies for land conservation. American Journal of Agricultural Economics, 88(1), 28-42.

Ozanne, A., Hogan, T., \& Colman, D. 2001. Moral hazard, risk aversion and compliance monitoring in agri-environmental policy. European Review of Agricultural Economics, 28(3), 329-348.

Plantinga, Andrew J., Lubowski, Ruben N., \& Stavins, Robert N. 2002. The effects of potential land development on agricultural land prices. Journal of Urban Economics, 52(3), 561-581.

Roe, B., Irwin, E.G., \& Morrow-Jones, H.A. 2004. The effects of farmland, farmland preservation, and other neighborhood amenities on housing values and residential growth. Land Economics, 80(1), 55-75. 
Towe, C. 2010. Testing the Effect of Neighboring Open Space on Development Using Propensity Score Matching. In: 2010 Annual Meeting, July 25-27, 2010, Denver, Colorado. Agricultural and Applied Economics Association.

Uthes, S., Matzdorf, B., Müller, K., \& Kaechele, H. 2010. Spatial targeting of agrienvironmental measures: cost-effectiveness and distributional consequences. Environmental management, 46(3), 494-509.

Wu, J.J., \& Irwin, E.G. 2008. Optimal land development with endogenous environmental amenities. American Journal of Agricultural Economics, 90(1), 232-248.

Wu, JunJie. 2006. Environmental amenities, urban sprawl, and community characteristics. Journal of Environmental Economics and Management, 52, 527-547.

Wu, JunJie, \& Lin, Haixia. 2010. The Effect of the Conservation Reserve Program on Land Values. Land Economics, 86(1), 1-21.

Wu, JunJie, \& Plantinga, Andrew J. 2003. The influence of public open space on urban spatial structure. Journal of Environmental Economics and Management, 46, 288309.

Wunder, S., Engel, S., \& Pagiola, S. 2008. Taking stock: A comparative analysis of payments for environmental services programs in developed and developing countries. Ecological Economics, 65(4), 834-852. 
Les autres documents de travail du GRANEM accessibles sur le site Web du laboratoire à l'adresse suivante : (www.univ-angers.fr/granem/publications) :

\begin{tabular}{|c|c|c|c|c|}
\hline Numéro & Titre & Auteur(s) & Discipline & Date \\
\hline 2008-01-001 & $\begin{array}{l}\text { The Cognitive consistency, the endowment effect and the } \\
\text { preference reversal phenomenon }\end{array}$ & Serge Blondel, Louis Lévy-Garboua & Théorie du Risque & octobre 2008 \\
\hline $2008-02-002$ & $\begin{array}{l}\text { Volatility transmission and volatility impulse response } \\
\text { functions in European electricity forward markets }\end{array}$ & Yannick Le Pen, Benoît Sévi & Econométrie Appliquée & octobre 2008 \\
\hline 2008-03-003 & $\begin{array}{l}\text { Anomalies et paradoxes dans le cas des choix alimentaires } \\
\text { : et si les carottes n'étaient pas oranges? }\end{array}$ & $\begin{array}{l}\text { Serge Blondel, Christophe Daniel, Mahsa } \\
\text { Javaheri }\end{array}$ & Economie Expérimentale & octobre 2008 \\
\hline 2008-04-004 & $\begin{array}{l}\text { The effects of spatial spillovers on the provision of urban } \\
\text { environmental amenities }\end{array}$ & $\begin{array}{l}\text { Johanna Choumert, Walid Oueslati, Julien } \\
\text { Salanié }\end{array}$ & Economie du Paysage & octobre 2008 \\
\hline 2008-05-005 & $\begin{array}{l}\text { Why do rational people vote in large elections with costs } \\
\text { to vote? }\end{array}$ & Serge Blondel, Louis Lévy-Garboua & Théorie du Risque & novembre 2008 \\
\hline 2008-06-006 & Salaires, conditions et satisfaction au travail & Christophe Daniel & Economie du Travail & novembre 2008 \\
\hline 2008-07-007 & $\begin{array}{l}\text { Construction communicationnelle du stock de } \\
\text { connaissances de la compétence collective - Contribution } \\
\text { à partir d'une conversation. }\end{array}$ & Nicolas Arnaud & Gestion des Ressources Humaines & décembre 2008 \\
\hline $2008-08-008$ & $\begin{array}{l}\text { On the non-convergence of energy intensities: evidence } \\
\text { from a pair-wise econometric approach }\end{array}$ & Yannick Le Pen, Benoît Sévi & Econométrie Appliquée & décembre 2008 \\
\hline 2008-09-009 & Production of Business Ethics & Guido Hülsmann & Economie Politique & décembre 2008 \\
\hline 2008-10-010 & Time preference and investment expenditure & Guido Hülsmann & Economie Politique & décembre 2008 \\
\hline 2008-11-011 & $\begin{array}{l}\text { Le marché de la photographie contemporaine est-il soluble } \\
\text { dans celui de l'art contemporain? }\end{array}$ & Dominique Sagot-Duvauroux & Economie de la Culture & décembre 2008 \\
\hline 2008-12-012 & $\begin{array}{l}\text { The newsvendor problem under multiplicative background } \\
\text { risk }\end{array}$ & Benoît Sévi & Microéconomie de l'Incertain & décembre 2008 \\
\hline 2009-01-013 & $\begin{array}{l}\text { Complémentarité de la collaboration électronique et de } \\
\text { l'investissement relationnel : étude de cas exploratoire } \\
\text { d'un SIIO dans le secteur du meuble }\end{array}$ & Redouane Elamrani, Nicolas Arnaud & Organisation & avril 2009 \\
\hline 2009-02-014 & $\begin{array}{l}\text { On the realized volatility of the ECX CO2 emissions } 2008 \\
\text { futures contract: distribution, dynamics and forecasting }\end{array}$ & Julien Chevallier, Benoît Sévi & Finance & mai 2009 \\
\hline 2009-03-015 & $\begin{array}{l}\text { The communicational making of a relation-specific skill: } \\
\text { contributions based on the analysis of a conversation to } \\
\text { strategy-as-practice and resource-based view perspectives }\end{array}$ & Nicolas Arnaud & Stratégie & juin 2009 \\
\hline 2009-04-016 & $\begin{array}{l}\text { Le droit d'auteur, incitation à la création ou frein à la } \\
\text { diffusion? Une analyse empirique du cas de la création } \\
\text { télévisuelle }\end{array}$ & Françoise Benhamou, Stéphanie Peltier & Economie de la Culture & septembre 2009 \\
\hline 2009-05-017 & $\begin{array}{l}\text { Diversity analysis in cultural economics: theoretical and } \\
\text { empirical considerations }\end{array}$ & $\begin{array}{l}\text { Françoise Benhamou, Renato G. Flôres Jr., } \\
\text { Stéphanie Peltier }\end{array}$ & Economie de la Culture & septembre 2009 \\
\hline 2009-06-18 & $\begin{array}{l}\text { L'épargne retraite en entreprise : un état des lieux au } \\
\text { regard de l'expérience américaine }\end{array}$ & Fabrice Pansard, Bruno Séjourné & Finance & septembre 2009 \\
\hline 2009-07-19 & Options introduction and volatility in the EU ETS & $\begin{array}{l}\text { Julien Chevallier, Yannick Le Pen, Benoît } \\
\text { Sévi }\end{array}$ & Econométrie Appliquée & septembre 2009 \\
\hline $2009-08-20$ & $\begin{array}{l}\text { Modeling strategic interactions between firms and local } \\
\text { authorities - The case of a biotechnology cluster }\end{array}$ & Alain Berro, Isabelle Leroux & Economie des réseaux & septembre 2009 \\
\hline 2009-09-21 & $\begin{array}{l}\text { The strategy adopted by non-profit care services } \\
\text { organizations in dealing with the new French regulatory } \\
\text { system: strategic coalitions and reterritorialisation of } \\
\text { activities }\end{array}$ & $\begin{array}{l}\text { Isabelle Leroux, Laurent Pujol, } \\
\text { Eric Rigamonti }\end{array}$ & Economie Sociale & novembre 2009 \\
\hline 2009-10-22 & Une nouvelle lecture du territoire par la limite & Jean-Claude Taddei & Territoire & novembre 2009 \\
\hline $2010-01-23$ & $\begin{array}{l}\text { Adoption of new identity-based services: Proposition of a } \\
\text { conceptual model based on TAM, DOI and perceived risks }\end{array}$ & Caroline Lancelot Miltgen & e-marketing & juillet 2010 \\
\hline 2010-02-24 & $\begin{array}{l}\text { Young Europeans' motivations, perceived risks and } \\
\text { requirements regarding electronic identification : Some } \\
\text { comparative results from focus groups in four EU } 27 \\
\text { countries }\end{array}$ & Caroline Lancelot Miltgen & e-marketing & décembre 2010 \\
\hline $2010-03-25$ & $\begin{array}{l}\text { Analyse du risque de non-exécution des ordres à la bourse } \\
\text { de Paris }\end{array}$ & Angélique Aubier Piron & Finance & décembre 2010 \\
\hline 2011-01-26 & $\begin{array}{l}\text { Who cares? Europeans' attitudes towards the disclosure of } \\
\text { personal identity data }\end{array}$ & $\begin{array}{l}\text { Caroline Lancelot Miltgen, Margherita } \\
\text { Bacigalupo, Wainer Lusoli }\end{array}$ & $\begin{array}{l}\text { Systèmes d'information et e- } \\
\text { marketing }\end{array}$ & janvier 2011 \\
\hline 2011-02-27 & $\begin{array}{l}\text { Le rôle des Business Angels dans le financement de } \\
\text { l'innovation radicale. }\end{array}$ & Catherine Deffains-Crapsky & Finance entrepreneuriale & avril 2011 \\
\hline $2011-03-28$ & The EU Financial Reform facing the Global Context & Dominique Perrut & Economie financière & mai 2011 \\
\hline 2011-04-29 & A simple test of the sustainable development hypothesis & Serge Blondel & Economie expérimentale & septembre 2011 \\
\hline $2011-05-30$ & $\begin{array}{l}\text { Evaluation d'un nouveau produit alimentaire : le rôle de la } \\
\text { congruence et du packaging }\end{array}$ & $\begin{array}{l}\text { Gaëlle Pantin-Sohier et Caroline Lancelot } \\
\text { Miltgen }\end{array}$ & Comportement du consommateur & octobre 2011 \\
\hline 2011-06-31 & $\begin{array}{l}\text { Une mesure de risque extrême agrégée : risque de marché } \\
\text { et risque de liquidité }\end{array}$ & Angélique Aubier-Piron & Finance & octobre 2011 \\
\hline 2011-07-32 & $\begin{array}{l}\text { When should a French Investor use a Dollar-Cost } \\
\text { Averaging Strategy? }\end{array}$ & Philippe Compaire et Bruno Séjourné & Finance & octobre 2011 \\
\hline 2011-08-33 & $\begin{array}{l}\text { Conformisme à la norme et performance : la franchise } \\
\text { dans le mix organisationnel }\end{array}$ & $\begin{array}{l}\text { Christophe Daniel, Regis Dumoulin et Claire } \\
\text { Gauzente }\end{array}$ & Stratégie et organisation & octobre 2011 \\
\hline $2011-09-34$ & The structure of production reconsidered & Guido Hülsmann & Economie politique & décembre 2011 \\
\hline $2012-01-35$ & $\begin{array}{l}\text { The quality of private monitoring in European banking: } \\
\text { completing the picture }\end{array}$ & Adrian Pop et Diana Pop & Economie financière & février 2012 \\
\hline $2012-02-36$ & $\begin{array}{l}\text { Urban sprawl occurrence under spatially varying } \\
\text { agricultural bid-rent and amenities }\end{array}$ & $\begin{array}{l}\text { Thomas Coisnon, Walid Oueslat et Julien } \\
\text { Salanié }\end{array}$ & Economie urbaine & septembre 2012 \\
\hline $2012-01-37$ & Le renouveau du paiement du dividende en actions & Caroline Marie-Jeanne & Finance & mars 2012 \\
\hline
\end{tabular}


